\title{
Uusioersily
}

\section{Stratigraphy and internal structure of wind-dominated barrier islands (dune and machair) of the Outer Hebrides, Scotland}

Pile, J., Cooper, A., \& Jackson, DWT. (2019). Stratigraphy and internal structure of wind-dominated barrier islands (dune and machair) of the Outer Hebrides, Scotland: Stratigraphy and internal structure of winddominated barrier islands . Earth Surface Processes and Landforms, 44(7), 1482-1493. [16308154]. https://doi.org/10.1002/esp.4579

Link to publication record in Ulster University Research Portal

\section{Published in:}

Earth Surface Processes and Landforms

Publication Status:

Published (in print/issue): 15/06/2019

DOI:

10.1002/esp.4579

\section{Document Version}

Author Accepted version

\section{General rights}

Copyright for the publications made accessible via Ulster University's Research Portal is retained by the author(s) and / or other copyright owners and it is a condition of accessing these publications that users recognise and abide by the legal requirements associated with these rights.

\section{Take down policy}

The Research Portal is Ulster University's institutional repository that provides access to Ulster's research outputs. Every effort has been made to ensure that content in the Research Portal does not infringe any person's rights, or applicable UK laws. If you discover content in the Research Portal that you believe breaches copyright or violates any law, please contact pure-support@ulster.ac.uk. 
Stratigraphy and internal structure of wind-dominated barrier islands (dune and machair) of the Outer Hebrides, Scotland

J. Pile ${ }^{1,2}$, J.A.G. Cooper ${ }^{1,3}$, D.W.T. Jackson ${ }^{1}$

1. School of Geography and Environmental Sciences, Ulster University, Cromore Road, Coleraine, Northern Ireland, UK

2. Visiting Fellow, Faculty of Science and Technology, Bournemouth University, Fern Barrow, Poole, Dorset, UK

3. Discipline of Geology, University of KwaZulu-Natal, Westville Campus, Private Bag X54001, Durban 4000, South Africa

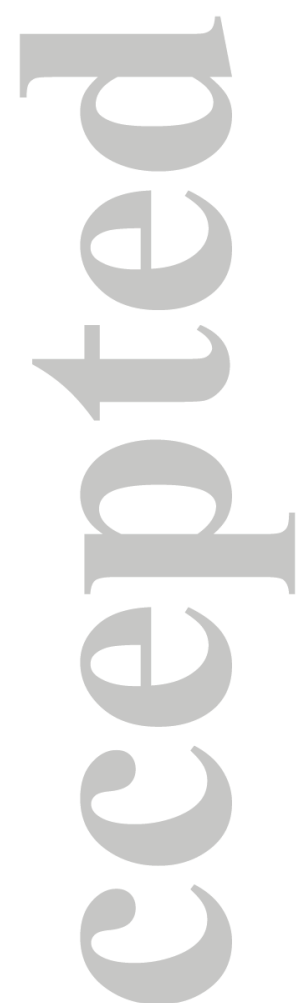

This article has been accepted for publication and undergone full peer review but has not been through the copyediting, typesetting, pagination and proofreading process which may lead to differences between this version and the Version of Record. Please cite this article as doi: $10.1002 /$ esp.4579 


\section{Abstract}

The barrier islands that fringe the western shore of the Outer Hebrides are globally unusual in that they are developed on a planated bedrock (strandflat) surface. They also contain the most extensive area of machair (a distinctive vegetated sandy plain) in the British Isles. This paper presents the first investigation of the internal structure and morphology of these barrier islands and investigates the controls on their structure. The barriers form extensive (300-1000 metres wide) but thin (1.5-2 m) surficial deposits typically resting on bedrock. In areas where depressions exist in the bedrock, and where sediment supply permits, transgressive dunes underlie the machair. A distinctive machair facies of sub-horizontal, undulating reflections, which are laterally continuous over tens of metres is the dominant component of the barriers at each site. This reflects episodic deposition of windblown sand up to the level of the water table. Thereafter any additional sand is transported through the system to accumulate in topographic lows as lake fills, or on topographic highs as 'high machair'. Seven radar facies were identified, the extent and presence of which vary between the study sites. Bedrock topography and sediment supply are interpreted as the dominant controls on variability in barrier structure.

Keywords: GPR, Machair, Barrier Islands, Outer Hebrides, planated bedrock, strandflat 


\section{Introduction}

Coastal barriers and barrier islands are dynamic coastal landforms that occur, and have been studied, worldwide. Barriers and barrier islands are generally characterised as being narrow, elongate features that have formed parallel to the shore and are separated from the mainland by a shallow channel, bay or lagoon. They comprise six distinctive elements: (1) mainland; (2) backbarrier lagoon; (3) inlet and inlet deltas; (4) barrier island; (5) barrier platform; and (6) shoreface (Oertel, 1985). Barrier lagoon systems are diverse in morphology and dimensions and are present on over $6.5 \%$ of the world's coastlines (Cooper, et al., 2012). Although it contains all of the elements considered by (Oertel, 1985) as characteristic of barrier island coasts, the $90 \mathrm{~km}$-long Outer Hebrides system was identified as an endmember of barrier island form in terms of the extreme level of control of underlying bedrock on barrier/lagoon morphology and behaviour (Cooper, et al., 2012).

Unusual among barrier islands, such as the paraglacial barriers described by (Van Heteren, et al., 1998), but similar to other coastal environments (Backstrom, et al., 2009), the system's formation and transgressive evolution has been primarily influenced by the underlying bedrock surface, which is a near-planar strandflat of Precambrian Gneiss (Dawson, et al., 2013).

The Hebridean barrier islands are unusual in their surface morphology, being up to 2 $\mathrm{km}$ wide but typically only $1.5-2 \mathrm{~m}$ thick. The dominant morphological element is a vegetated sandy plain known as 'machair' which comprises ca. $90 \%$ of the area of the entire Hebridean beach/dune system (Ritchie, 2005). Machair is a plain composed of calcareous sand that typically supports a sandy, grassland vegetation (Moss and Dickinson, 1979, Ritchie, 2005) and has a high conservation value 
(Angus, 1994, Angus, 1997). It is confined to the exposed western coasts of Scotland and Ireland (Bassett and Curtis, 1985), although equivalent environments have also been described from New Zealand (Wilson, et al., 1993). The sand is introduced by episodic aeolian activity but its upper surface is regarded as an erosional one produced by deflation to the water table. Consequently, the ground is wet in the winter when the water table crops out. The machair system has long been the subject of geomorphological and ecological investigation (Gilbertson, et al., 1999, Hansom and Angus, 2005, Mate, 1992, Ritchie, 1967, Ritchie, 1971, Ritchie, 1976, Ritchie, 1979) and a number of models of its evolution and development have been presented. These were reviewed and summarised by (Gilbertson, et al., 1999).

The aim of this paper is to describe the contemporary form and internal structure of the Hebridean barrier islands at contrasting locations and to interpret the stratigraphy and form in terms of barrier island processes and evolution in this unusual environment. To this end, we investigate the thickness and internal structure of the Western Isles barrier islands using Ground Penetrating Radar (GPR). The GPR data are analysed using radar facies classification, and ground-truthed by coring and inspection/logging of natural sections.

The application of ground penetrating radar (GPR) to coastal sedimentary environments has yielded important information on the subsurface architecture and facies arrangement in a variety of settings, including coastal dunes (Bristow, et al., 2000, Girardi and Davis, 2010), beaches (Bennett, et al., 2009, Dickson, et al., 2009, Neal, et al., 2003), spits, barriers and barrier islands (Buynevich and Donnelly, 2006, Craig, et al., 2012, Garrison, et al., 2010, Neal, 2004, Pile, et al., 2016, Van 
Heteren, et al., 1998). The GPR investigation of barriers and barrier islands also allows comparison with ancient barrier systems preserved in outcrop (Jahnert, et al., 2012).

\section{Study area}

The western coast of the Western Isles (Outer Hebrides) of Scotland between latitudes $57^{\circ} 05^{\prime}$ and $58^{\circ} 31^{\prime} \mathrm{N}$ is framed by resistant bedrock composed primarily of Lewisian Gneiss (Proterozoic) with a discontinuous and thin Quaternary sediment cover (Fettes, et al., 1992). Tidal range varies from $3.8 \mathrm{~m}$ on spring tides to $2.9 \mathrm{~m}$ on neaps (Ritchie, 1967). Most waves approach from between 250 and $270^{\circ}$ (Figure 1; Garrad Hassan and Partners, 2002) and offshore wave energy is high, with a long term mean $\mathrm{H}_{\mathrm{s}}$ of $3.3 \mathrm{~m}$ (Jericho Project, 2000). The annual average wave power density has been reported as $65 \mathrm{~kW} / \mathrm{m}$ (Garrad Hassan and Partners, 2002) and 75 $\mathrm{kW} / \mathrm{m}$ (Oertel, 1985), a level equalled only in the Southern Ocean (Barstow, et al., 2009).

This deepwater wave energy is dissipated on the wide, subtidal bedrock platform and the nearshore wave field is described as "severely depth limited' (Richards and Phipps, 2011). Wave energy along the coast of the Uists is between 3.9 and 18.8 kW/m (Garrad Hassan and Partners, 2002). Modelling of storm waves (Wolf, 2007) shows a zone of marked wave energy reduction corresponding to the submerged low gradient rock platform. The shoreline is consequently relatively low energy and experiences significant wave influences only during periodic storms and surges (Dawson, et al., 2007, Wolf, 2007). 
The Western Isles wind regime (Manley, 1979) is also among the most energetic in the world. Predominant winds are from the SSW (Figure 1) and average wind speeds are high year-round (Orme, et al., 2016). Monthly average wind speed ranges from 15 knots $(8 \mathrm{~m} / \mathrm{s})$ in winter to 12 knots $(6 \mathrm{~m} / \mathrm{s})$ in summer. $60 \%$ of all winds exceed $5.5 \mathrm{~m} / \mathrm{s}$.

$<$ Figure 1 here $>$

The pattern of Late glacial and early Holocene sea level in the Outer Hebrides is only inferred by modelling studies (Jordan, et al., 2010). Empirical data from the mid-late Holocene points to a relative sea level rise of about $3.5 \mathrm{~m}$ over the past 5000 years (Jordan, et al., 2010). Tide gauge records show that relative sea level is currently rising between 2 and 4.5 mm/yr (Gilbertson, et al., 1999).

\section{Study sites}

Investigations focussed on three sites, each with a distinctive geomorphological setting. Milton is located on South Uist (Figure 2). The planated bedrock (strandflat) extends from onshore to the shallow offshore zone, where it takes the place of a shoreface. A $100 \mathrm{~m}$-wide sandy beach occupies the intertidal and supratidal zone. The beach contains a $5 \mathrm{~m}$-wide gravel facet at high tide. This is backed by an $3 \mathrm{~m}$ high erosional scarp cut into wind-blown sand that forms the seaward margin of the machair. The 300-400 m wide machair plain has a gently undulating surface that drops in elevation from $8.5 \mathrm{~m}$ at its seaward edge to $3 \mathrm{~m}$ at its landward termination. The surface is vegetated and has been cultivated. The machair terminates landward on the planar bedrock surface or on scattered lochs (perched lagoons), that occupy 
topographic lows in the bedrock surface and which have been impounded by the machair.

At Ormiclate (Figure 2) the planated bedrock surface extends directly from onshore to offshore. A $100 \mathrm{~m}$-wide sandy intertidal beach is backed by a high tide gravel facet that is banked against dune scarp at the seaward edge of the $1200 \mathrm{~m}$-wide machair complex. The $100 \mathrm{~m}$-wide frontal dune drops from $7 \mathrm{~m}$ to $3 \mathrm{~m}$ OD elevation within $100 \mathrm{~m}$ of the beach and is replaced by a 300-400 m wide, low-lying, wet peaty surface, interspersed with low hillocks. Landward of this, the vegetated sandy surface rises again to reach $7 \mathrm{~m}$ OD at its landward margin where the underlying bedrock is exposed. Occasional small lochs are impounded along the landward margin in bedrock lows. The wet and dry sections of machair that reflect its elevation changes, are marked by the absence and presence, respectively, of cultivation. Faint plough marks in the wet machair area, indicate that it is occasionally cultivated when conditions permit.

Baleshare (Figure 2) and the adjacent island of Kirkibost are barrier islands separated by tidal inlets with well-developed tidal deltas. They owe their existence to the presence of a deep and wide bedrock depression in which a tidal basin has been impounded by the barrier, rather than a perched loch. Baleshare contains a small area of bedrock outcrop, flanked by two sand barriers. The northern barrier extends northwest from the bedrock outcrop, and comprises a $100 \mathrm{~m}$-wide sandy beach backed by a $100 \mathrm{~m}$-wide low vegetated dune. The $1000 \mathrm{~m}$-wide southern barrier comprises several dune ridges with a broad stretch of low- lying machair scattered with small hummocky dunes. This is backed by the sandy intertidal flats of the tidal 
basin. In the mid-section of Baleshare, the machair rests on planated bedrock, and impounds several small lochs. In contrast to Milton and Ormiclate, the sandy beach is fronted by a sandy shoreface.

$<$ Figure 2 around here>

\section{Methods}

\section{Ground penetrating radar}

Ground penetrating radar is a non-invasive subsurface imaging technique, which effectively displays an approximate cross section of the sub-surface structure, aligned in the direction of survey. In order to investigate the internal structure and geometry of the machair at the study sites, : Milton and Ormiclate on South Uist and Baleshare, on North Uist (Figure 2), a minimum of one long (200-800 m), approximately shore-normal, 2D traverse was undertaken across the Machair from the hinterland to, at least, the landward edge of the coastal dune system.

The traverses were undertaken using a Sensors and Software PulseEkko Pro system coupled with unshielded antennae with a central frequency of $200 \mathrm{MHz}$. The antennae were mounted on a sled in the perpendicular broadside configuration and fixed at the recommended $0.5 \mathrm{~m}$ spacing. To establish location and topography of the traverse lines a Trimble 5800 Differential Global Positioning System (DGPS) was mounted at the midpoint of the antennae and GPS readings were taken and recorded concurrently with the GPR survey. Data were collected continuously whilst the GPR/GPS sled assembly was towed along the traverse lines at a slow walking pace to give an approximate collection interval of $0.1 \mathrm{~m}$ (dependent on terrain), with 32 traces stacked at each point. 
GPR data were post-processed and topographically corrected using Reflex-W software (Reflex-Win v.7, K.J. Sandmeier, 1997-2013). The same basic processing steps were applied to each trace and consisted of: Editing Trace header values addition of GPS data to the GPR lines via GPS collection times; Application of a "Dewow" filter - this removes low frequency electrical "noise" or bias in the traces that is generated by the equipment; Background removal $-a$ filtering process that reduces the visual appearance of multiples of the air/ground waves and antenna ringing by removing the normalised average trace from all traces; Automatic Gain Control (AGC) - a gain of 500 was applied; Topographic correction - applying GPS elevation values to the GPR line; Running average (2-traces) - performs a running average enhancing gently dipping reflections. In addition to the main processing steps, other optional processing filters were applied to certain profiles to clarify and aid interpretation. Velocities of the subsurface materials were determined by interactively adapting the electromagnetic wave velocity to match diffraction hyperbolae present within GPR lines. Using this method a velocity $0.06 \mathrm{~m} / \mathrm{ns}$ was found to be the best fit for the diffraction hyperbolae. This velocity is typical of saturated sands, sands and gravels and freshwater peats (Jol and Bristow, 2003, Neal and Roberts, 2000, Switzer, et al., 2006). Although advanced processing algorithms can be used to resolve thin beds (Gouramanis, et al., 2015), the vertical resolution of GPR is generally accepted to be a quarter of the wavelength associated with the selected antenna frequency (Neal and Roberts, 2000) and is therefore limited to $0.075 \mathrm{~m}$ for $200 \mathrm{MHz}$ antennae.

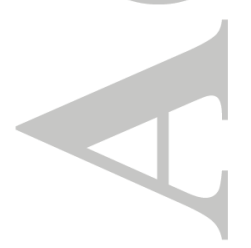


The radargrams for each traverse were examined and interpreted using a radar facies approach advocated by (Van Heteren, et al., 1998), (Neal and Roberts, 2000), (Jol and Bristow, 2003) and (Neal, 2004). Ground-truthing of the GPR records was conducted using field examination of exposed sections plus gouge augering.

A 380 m-long GPR line at Milton (Figure 3) extended across a 'typical' machair-type environment whose surface slopes gently landward from the seaward scarp until it encounters the underlying bedrock surface.

$<$ Figure 3 around here $>$

Three approximately shore normal GPR lines were shot at Ormiclate, each approximately $700 \mathrm{~m}$ long with a $50 \mathrm{~m}$ separation. The line presented here (OM1 Figure 4) is the most southerly line at this location and is representative of all three lines. Profile OM1 (Figure 4) runs approximately shore normal, for $710 \mathrm{~m}$. Along the transect line there was evidence of ploughing, with bare sand visible. From 100 to $300 \mathrm{~m}$ along the profile the elevation drops gently but steadily from $7 \mathrm{~m}$ to $5 \mathrm{~m}$ along a smooth slope. From $300 \mathrm{~m}$ to $630 \mathrm{~m}$, the land gradually falls from $5 \mathrm{~m}$ to around 3 m OD. A number of small hillocks, 1-1.5 m high, occur on the lower lying machair surface. From $630 \mathrm{~m}$ to $710 \mathrm{~m}$ (end of profile) the land again rises to a height of $7 \mathrm{~m}$. $<$ Figure 4 around here $>$

Two GPR profile lines, BS1 and BS2 (each $270 \mathrm{~m}$ long) were shot at Baleshare. BS1 (Figure 5a) extended from the beach, through a vertical sand bluff, through an undulating dune topography, with prominent crests and troughs, some slopes of which were steep enough to require a break in data collection and "portage" of GPR 
equipment downslope. The transect continued across lower elevation dunes, levelling out onto a wet marshy surface. BS2 (Figure 5b), in contrast, extended across a gently undulating planar surface with only slight changes in elevation along transect.

$<$ Figure 5 around here $>$

\section{Sediment Cores and Sections}

To aid in interpretation and check depth corrections, a series of cores were taken at each site to ground truth the GPR data. The cores were taken using a $1 \mathrm{~m}$ gouge auger, with extension bars. Each borehole was situated along or close to the GPR lines and located using a Garmin Oregon 550T handheld GPS. The cores were described and logged in the field using standard engineering soil descriptions. Where natural sections were present close to or situated along the line of the GPR traverse, these sections were cleaned and logged. Due to groundwater conditions and the presence of flowing/running sands (where high pore pressures force sand up an uncased borehole), depth penetration and core recovery at several core locations was limited.

Core locations are marked on the site maps (Figure 2) and graphic logs for the corresponding core logs (Tables 1-7) are shown in Figure 6. A natural exposure at Baleshare is also shown (Figure 7).

$<$ Tables 1-7 around here> 
$<$ Figures 6 and 7 here $>$

\section{Results}

\section{Radar Facies}

Several distinctive radar facies and bounding surfaces were identified from the radargrams. They are described below and their characteristics are summarised in Table 8.

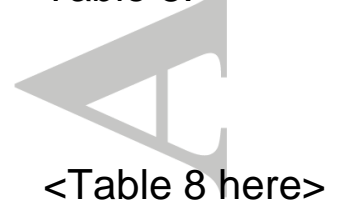

\section{RF1.}

Radar facies 1 (RF1) underlies most of the profile length at Milton (Figure 3) and Ormiclate (Figure 4). It has a characteristic undulating top surface that dips gently seaward and is characterised by numerous, overlapping hyperbolae. Below the undulating surface the GPR signal is greatly attenuated, with evidence of antenna "ringing" and multiples of the ground surface.

RF2.

At Baleshare (Figure 5), RF1 is not apparent on the radargrams due to lack of penetration and signal attenuation. Instead, the base of the radargram comprises Radar Facies 2 (RF2). This unit is at least $4.5 \mathrm{~m}$ thick and is characterised by a 
series of internal landward-dipping reflections, whose geometry changes across the profile, identifying three sub-facies (Figure 5b), all of which contain occasional isolated hyperbolic reflections. At the seaward end of the profile (RF2a) major reflections separate sediment units about $1.5 \mathrm{~m}$ thick. These units dip steeply $(0.25)$ landward and contain some short, discontinuous sub-horizonal reflections that are truncated by main reflections. The units dip steeply landwards (0.5) by ca. $5 \mathrm{~m}$ beyond which they become sub-horizontal. Landward (RF2b), the major reflections delineate sediment units of $2 \mathrm{~m}$ thick that dip more gently landward (0.16). The major surfaces are interspersed with short, discontinuous, convex reflections. More landward still (RF2c) the major reflections are dominant and dip more gently landward (between 0.008 and 0.01). They exhibit a range of planar, convex and concave morphologies. Each subsequent reflection overlies the previous reflection, indicating that the facies is younging landwards.

The upper surface of this unit is sub-horizontal but gently undulating. It occurred less than $1 \mathrm{~m}$ below the water table at the time of the survey.

\section{RF3.}

At the landward end of profile BS2 at Baleshare (Figure 5b), RF2 is conformably overlain by RF3. This facies is at least $3 \mathrm{~m}$ thick and is characterised by slightly concave, sub-horizontal to horizontal and laterally continuous reflections at decimetre vertical spacing. Occasional hyperbolic reflections are present within the unit. The facies is also present at the landward end of the Milton profile (Figure 3).

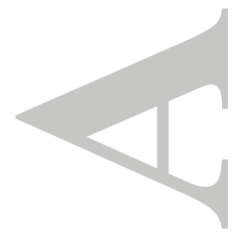




\section{RF4}

The dominant surficial facies at all sites is RF4 (Figs. 3-5) which represents the main 'machair' land surface. At Ormiclate and Milton it overlies RF1 and at Baleshare it overlies RF2. It is a $1.5-2 \mathrm{~m}$ thick, near-horizontal unit at least $600 \mathrm{~m}$ wide at

Ormiclate. It is characterised by sub-horizontal, undulating reflections, which are laterally continuous over tens of metres and which truncate each other at low angles. It was recorded at elevations up to $7 \mathrm{~m}$ OD. In places, especially at the topographic highs of the dunes, a series of ground-following reflections, occasionally steeply dipping, are present. At Baleshare (Figure 5) the radargram also reveals a series of concave depressions within RF4, which cut into the underlying radar facies (RF2), and are themselves infilled with short $(5-10 \mathrm{~m})$ undulating horizontal to subhorizontal reflections (Figure 5).

\section{RF5.}

At the seaward end of the Milton profile, a prominent reflection marks the base of RF5 and the top of the underlying facies RF1 and RF4 (Figure 3). The basal reflection truncates reflections in underlying RF4. RF5 occupies a topographically high $(5-8 \mathrm{~m})$ location next to the modern beach and is ca. $100 \mathrm{~m}$ wide. It contains a series of undulating, sub-horizontal reflections with numerous overlapping hyperbolae, the apices of which meet at, or close to, the surface. These clusters of multiple, overlapping, shallow hyperbolae are mainly found above the water table.

\section{RF6.}

At the seaward end of the Ormiclate transect (Figure 4), the land rises steeply from $2.5 \mathrm{~m}$ to over $7 \mathrm{~m}$ in a distance of just $100 \mathrm{~m}$. The associated surface radar facies 6 
(RF6), is chaotic, with a series of short, landward- and seaward-dipping reflections, and also some horizontal and sub-horizontal reflections. RF6 occurs as a tapering wedge, over $3 \mathrm{~m}$ thick at its seaward end, gradually thinning landwards. It rests on top of RF1 and RF4.

\section{RF7.}

At Ormiclate (Figure 4) a distinctive, but intermittent, facies (RF7) is preserved in small (1 m-high), vegetated hummocks and intervening depressions on the surface of RF4. The hummocks themselves contain short, discontinuous reflections that are sub-horizontal. Some of these are truncated at the surface of the hummocks, and are varied in character, with some reflections appearing to be infill the space between surface sand hillocks.

\section{RF8}

Forming a topographic high and characterised by a series of seaward dipping, continuous reflections that gradually reduce in gradient and onlap the surface of RF4, RF8 is located in the centre of line BS1 at Baleshare (Figure 5a). RF8 unconformably overlies a bright reflection/bounding surface that delineates a depression within RF4.

\section{$\underline{\text { Interpretation }}$}

The lack of penetration and presence of hyperbolic reflections on the surface lead us to interpret RF1 as bedrock. Bedrock (Lewisian Gneiss) crops out adjacent to each profile location where it was encountered. Across most of the profiles, the surface 
topographic undulations mimic the surface of RF1 showing that the upper machair surface is strongly influenced by underlying bedrock as postulated by Ritchie (1971),.

RF2a is developed adjacent to the shoreline at Baleshare and its steeply landwarddipping reflections are continuous from the surface to the base of the profile (maximum penetration depth of the GPR) where their gradient is reduced The contemporary upper beach at this location comprises sediment of cobble/pebble size, and the steeply dipping reflections likely represent the landward extension of a cobble beach ridge, the larger clast sizes being able to support the high angle of repose (Jol et al., 1996). The shorter internal reflections may represent small slumps within the gravel ridge system.

The less steeply dipping reflections of RF2b extend a further $50 \mathrm{~m}$ landward of the ridge crest. They are interpreted as sandy washover fans, deposited landward of the gravel ridge by periodic overwashing, similar to those noted in the region by Dawson et al. (2007) and Angus and Rennie (2014) after an extreme storm in 2006. The lower angle suggests sandy sediments with a lower angle of repose than the gravel ridge. The landward extent of washover during the storm of 2006 was of a similar extent. The third sub-facies (2c), overlies sub-facies $2 b$ indicating that the sequence is younging in the landward direction. Approximately $120-140 \mathrm{~m}$ along the transect, the dipping reflections are much "brighter", possibly indicating a hiatus in deposition, and a stabilisation of the land surface. The landward extent of this unit, coupled with the consistently landward-dipping reflections suggest landward progradation of an aeolian dune, the reflections representing successive slipfaces of the landwardadvancing sand body 
At Baleshare the surface conditions change from dunes to a wet flush/marsh environment at the junction of RF2 and RF3, with the shallower reflections of RF3 onlapping RF2. At Milton this change occurs at the junction of RF3 and RF4. Core M1B at Milton (Table 2, Figure 6) is entirely within RF3 and reveals wet flush/marsh deposits (organic-rich slits clays and sands) to a depth of $0.6 \mathrm{~m}$, overlying sand deposits (0.6-1.2 m), which in turn overlie clayey silts and silty clays, indicative of lacustrine deposition, to a depth of $1.5 \mathrm{~m}$. This suggests deposition in a water body of fine-grained organic-rich sediments interrupted by periodic influxes of wind-blown sand.

Radar Facies 4 (RF4) is the dominant surface unit of the barriers and is associated with the 'machair' (sandy plain) landscape. Core M1A (Table 1, Figure 6) reveals RF4 to be primarily composed of clean, shelly sand layers separated by thin organic rich horizons. At Ormiclate, two soil horizons were encountered in borehole OM1A (Table 3, Figure 6); the contemporary soil (0-0.2 m) overlying an older soil (0.2-0.4 m), which overlies a clean shell sand (Figure 6). Similar clean sands were encountered in OM1B and $\mathrm{OM} 1 \mathrm{C}(\mathrm{a})$, at 0.56 and $0.15 \mathrm{~m}$, respectively (Tables 5 and $5 a$, Figure 6). RF4 is revealed in section at Baleshare, BS1A, with a series of stable surfaces, comprising organic layers and pebble horizons, overlying medium to fine grained sand (Table 6, Figure 6). In core BS2A the present soil horizon (to a depth of $0.2 \mathrm{~m}$ ), overlies medium grained sands to a depth of $1.15 \mathrm{~m}$, where a compacted layer of sediment prevented further sample recovery (Table 7, Figure 6).

This unit thus appears to represent thin layers of aeolian sand deposited as laterally extensive sheets. Sand deposition is interrupted by periods of stability indicated by 
organic-rich soil horizons which may reflect natural vegetation growth and/or cultivation on the machair surface.

The location of RF5 and its landward-dipping reflections indicate it to represent aeolian accumulation in the contemporary foredune. Its base rests partly on bedrock (RF1) and partly truncates surfaces in the underlying RF4 to landward (Figure 3) indicating that it post-dates that unit, at least in part. A combination of ongoing sand supply and trapping by foredune vegetation likely led to vertical dune accumulation. The abundant hyperbolae are the result of rabbit burrowing of which there is much evidence at the surface. By virtue of its position and regular seaward-dipping reflections, RF6 is interpreted as being the stoss side of an early formed coastal foredune, which has been overprinted with RF5 as the foredune developed (Figure 4).

RF7 characterises small dune hummocks, resting on a deflation surface, that is probably water table controlled (Figure 4). These small hummocks occur sporadically over the surface and likely accumulate around vegetation as wind-blown sand traverses the wet surface of RF4. Core OM1B (Table 4, Figure 6) revealed some internal structure of the hillocks that is not resolvable by radar. The hillocks appear to sit on a former vegetated surface, encountered at $0.47 \mathrm{~m}$ in core OM1B, which in turn overlies medium grained shell sand. The presence of a former soil horizon indicates that the hillocks formed on top of former vegetated surface and are likely migrating across it either as intact aeolian features or as ephemeral accumulations that eventually break down and disperse. The sediment in the hummocks varies from coarse to medium grained shell sand. Cores $\mathrm{OM} 1 \mathrm{C}$ and 
OM1Ca (Table 5 and 5a, Figure 6) reveal that the inter-hillock surface sediments are organic rich, comprising peaty sands and sandy peats approximately $0.15 \mathrm{~m}$ thick, overlying coarse-grained, clean, shell sand.

With its seaward dipping reflections that start at a topographic high and gently decrease in angle, onlapping RF4, RF8 is interpreted as dune deposits that are filling a deflation hollow within the RF4 surface.

\section{Discussion}

The barrier sequences described here are of comparable width to barriers elsewhere (300-800 m), but differ from typical paraglacial barriers (Van Heteren, et al., 1998), in that they are exceptionally thin (average $2 \mathrm{~m}$ ). The subtidal units normally associated with typical barriers are absent. This can be attributed to the limited accommodation space, which is in turn influenced by the bedrock topography (Backstrom, et al., 2009, Dawson, et al., 2013). Instead the barriers are dominated by aeolian units, due to the strong wind regime and limited sediment supply, reflecting the prevalence of carbonate-dominated marine sands and a lack of eroding glacial sediments (Ritchie, et al., 2001).

The thin barriers rest directly on bedrock at Ormiclate and Milton. In contrast, the Baleshare profiles record the presence of a gravel barrier (RF2a), landward of which, a landward-prograding sequence of sands is preserved. This appears to have originated initially as overwash deposits (RF2b) proximal to the gravel barrier and then given way to landward-migrating wind-blown sand (RF2c) that likely represents migrating sand dunes, whose slip faces create the reflections in this unit. The upper 
surface of the unit containing RF2a-c is undulating and near-planar, suggesting it has been deflated before deposition of subsequent units (RF4).

The bulk of the barrier sediment (RF4) appears to represent wind-blown deposition of sand from the beach directly onto the planated bedrock surface. The crude bedding in the sandy sediment suggests a series of repeated sand blows moving sand from the beach source, followed by stabilisation events to build up a $2 \mathrm{~m}$ thick planar machair unit. Periods of stability are suggested by the presence of thin organic horizons within the sand body (Wilson, et al., 1993 ). Given the agricultural activity of the land, faint organic traces may represent the application of seaweed as a soil improver (Young, et al., 2015 ).

Vertical accretion of this unit is probably limited by the prevailing strong wind regime and the upper surface level is likely controlled by the water table. Excess sand that accumulates above the groundwater-controlled level is blown across the surface as a series of isolated (and likely ephemeral) sand hummocks (RF7).

Deposition of sand landward of the barrier occurs either in water bodies or marshes as represented by RF3, or in hillocks represented by RF7. Accumulation of this deflated sand in areas further landward where the bedrock slopes upwards is somewhat analogous to the deposition of spillover lobes at the downwind margin of dune blowouts (Hesp, 2002); Smyth et al., 2014, 2013, 2012, 2011). These sands that accumulate landward have locally been termed 'high machair' (Ritchie, 1976) and they are typically more quartz rich than foredunes (Gilbertson, et al., 1999, 
Ritchie, 1976), suggesting that their elevated and dry position facilitates leaching of carbonate by rainwater (Ritchie, 1976).

Contemporary foredunes are developed at the seaward edge of the machair plain at Ormiclate and Milton. These attain higher elevation than the machair surface to landward. This is attributed to more vigorous vegetation growth and associated sand trapping by strandline and foredune vegetation. Storm deposits were deposited on the rear slope of the foredune as a result of overtopping (Dawson, et al., 2007).

Analysis of the geomorphology and internal structure of the Hebrides barrier islands show several similarities, but also important differences with barriers elsewhere. Topographically, they are much lower. This seems to reflect the strong wind regime and relatively low sand volume, such that rather than forming extensive dunes, the sand is blown landwards and is held in place by the water table. The resulting internal structure of the barrier islands is dominated by the machair facies and washover is restricted to only a few locations. Observations following a severe storm surge in 2005 (Dawson, et al., 2007) reported widespread scarping and offshore sediment transport, while overwashing was restricted to a few localities and seldom extended more than $10-15 \mathrm{~m}$ inland.

Although RF4 is the dominant facies throughout the barrier system, the three sites show some variability in morphology and internal structure. Bedrock topography and local sediment availability appear to be the primary controls on this variability. At both Milton and Ormiclate bedrock is encountered at shallow depths and is covered by a thin (1.5-2 m) veneer of sediment whose upper surface topography mirrors the 
underlying bedrock. At Milton, the bedrock horizon dips gently landwards, with undulations in the bedrock being expressed at surface as ridges on the machair plain. At Ormiclate the bedrock horizon dips gently towards the sea. The water table is ultimately controlled by the bedrock and the wide, fairly flat and low elevation of the bedrock at Ormiclate leads to the formation of a wide area of wet machair. To form the extended dry machair area on the high ground landward of the wet machair, transport of sand through the system is envisaged during summer months when the water table is low. The vegetated dune hummocks provide an indication of one such mode of transport. In contrast, where the bedrock surface is low at the landward extent of the machair, wind-blown sand accumulates in water bodies or marshes.

At Baleshare, the accumulation of substantial transgressive dunes (at least $5 \mathrm{~m}$ thick and $200 \mathrm{~m}$ wide) took place in the lee of the coastal gravel ridge before deposition of the machair surface unit. This indicates a local sediment abundance that subsequently declined. This is a section of the barrier chain where bedrock topography is low and tidal inlets and deltas develop (Cooper et al., 2012). The closure or migration of an inlet could conceivably have led to abandonment of an ebb delta and the subsequent reworking and transfer of its sediment to the coast in the form of a trangressive dune. When the sediment supply failed, machair development took place on the upper surface of this sediment. At Baleshare, remobilisation of sediment, through deflation of the machair surface, has led to the formation of steep dunes, as can be seen along the line of BS1.

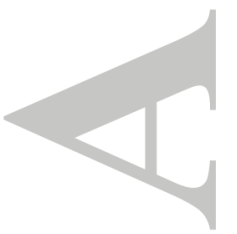




\section{Conclusions}

In contrast with most barrier systems, the Outer Hebrides barriers are dominated by aeolian processes and this is reflected in the stratigraphy and sediments. Overwash and gravel barrier facies are locally developed where sufficient accommodation space exists, but the strong wind regime and limited contemporary sediment supply mean that the predominant facies is the sand sheet or machair facies whose thickness and morphology is controlled by the water table. Sediment bypasses the machair facies as discrete hummocks and the landward depocentre depends on the topography. Where it rises, dunes may form above the water table (high machair) and where it declines, sand accumulates in water bodies or marshes.

Local foredune development on the seaward margin of the barriers is linked to sediment availability, and where they do develop, the foredunes are able to accrete vertically to higher elevations through the enhanced trapping ability of pioneering dune vegetation compared to the grass-dominated machair.

\section{Acknowledgements}

This study was undertaken within the framework of the EU Interreg Northern Periphery Project, Coastadapt which received funding from the European Regional Development Programme. We are grateful to David Muir of the Western Isles Council for helpful discussions. This paper is a contribution to IGCP 588 (Preparing for Coastal Change) and INQUA 1001 (Quaternary coastal change and records of 
extreme marine inundation on coastal environments). We thank Kilian McDaid and Lisa Rodgers for help in preparing the diagrams.

\section{References}

Angus S. 1994. The conservation importance of machair systems of the Scottish Islands, with particular reference to the Outer Hebrides. In The Islands of Scotland: $A$ Living Marine Heritage, Baxter JM, Usher MB (eds). HMSO: Edinburgh; 95-120. Angus S. 1997. The Outer Hebrides: The Shaping of the Islands. The White Horse Press: Harris

Backstrom J, Jackson D, Cooper J. 2009. Shoreface morphodynamics of a highenergy, steep and geologically constrained shoreline segment in Northern Ireland.

\section{Marine Geology 257 94-106}

Barstow S, Mork G, Lonseth L, Mathiesen JP. 2009. Worldwaves wave energy resource assessments from the deep ocean to the coast. . In Proceedings of the 8th European Wave and Tidal Energy Conference: Uppsala, Sweden.

Bassett JA, Curtis TGF. 1985. The Nature and Occurrence of Sand-Dune Machair in Ireland. Proceedings of the Royal Irish Academy. Section B: Biological, Geological, and Chemical Science 85B: 1-20

Bennett MR, Cassidy NJ, Pile J. 2009. Internal structure of a barrier beach as revealed by ground penetrating radar (GPR): Chesil beach, UK. Geomorphology 104: 218-229. DOI: 10.1016/j.geomorph.2008.08.015

Bristow CS, Chroston PN, Bailey SD. 2000. The structure and development of foredunes on a locally prograding coast: insights from ground-penetrating radar 
surveys, Norfolk, UK. Sedimentology 47: 923-944. DOI: 10.1046/j.1365-

3091.2000.00330.x

Buynevich IV, Donnelly JP. 2006. Geological Signatures of Barrier Breaching and

Overwash, Southern Massachusetts, USA. Journal of Coastal Research: 112-116 Cooper JAG, Jackson DWT, Dawson AG, Dawson S, Bates CR, Ritchie W. 2012.

Barrier islands on bedrock: A new landform type demonstrating the role of

antecedent topography on barrier form and evolution. Geology 40: 923-926. DOI:

$10.1130 / g 33296.1$

Craig MS, Jol HM, Teitler L, Warnke DA. 2012. Geophysical surveys of a pluvial lake barrier deposit, Beatty Junction, Death Valley, California, USA. Sedimentary Geology 269-270:28-36. DOI: 10.1016/j.sedgeo.2012.05.016

Dawson AG, Dawson S, Cooper JAG, Gemmell A, Bates R. 2013. A Pliocene age and origin for the strandflat of the Western Isles of Scotland: a speculative hypothesis. Geological Magazine 150: 360-366. DOI: 10.1017/s0016756812000568 Dawson AG, Dawson S, Ritchie W. 2007. Historical Climatology and coastal change associated with the 'Great Storm' of January 2005, South Uist and Benbecula, Scottish Outer Hebrides. Scottish Geographical Journal 123: 135-149. DOI: $10.1080 / 14702540701623784$

Dickson ME, Bristow CS, Hicks DM, Jol H, Stapleton J, Todd D. 2009. Beach Volume on an Eroding Sand-Gravel Coast Determined Using Ground Penetrating Radar. Journal of Coastal Research 255: 1149-1159. DOI: 10.2112/08-1137.1

Fettes DJ, Mendum JR, Smith DI, Watson JV. 1992. Geology of the Outer Hebrides. Memoir for 1:100 000 (solid edition) geological sheets, Lewis and Harris, Uist and Barra (Scotland) 
Garrad Hassan and Partners, 2002. Western Isles renewable energy study. Part 1: resource investigations. . Report \# 3069/GR/01 to Western Isles Council. , Garrison JR, Williams J, Potter Miller S, Weber ET, McMechan G, Zeng X. 2010. Ground-Penetrating Radar Study of North Padre Island: Implications for Barrier Island Internal Architecture, Model for Growth of Progradational Microtidal Barrier Islands, and Gulf of Mexico Sea-Level Cyclicity. Journal of Sedimentary Research 80: 303-319. DOI: 10.2110/jsr.2010.034

Gilbertson DD, Schwenninger JL, Kemp RA, Rhodes EJ. 1999. Sand-drift and Soil Formation Along an Exposed North Atlantic Coastline: 14,000 Years of Diverse Geomorphological, Climatic and Human Impacts. Journal of Archaeological Science 26: 439-469. DOI: 10.1006/jasc. 1998.0360

Girardi JD, Davis DM. 2010. Parabolic dune reactivation and migration at Napeague, NY, USA: Insights from aerial and GPR imagery. Geomorphology 114: 530-541.

DOI: 10.1016/j.geomorph.2009.08.011

Gouramanis C, Switzer AD, Polivka PM, Bristow CS, Jankaew K, Dat PT, Pile J, Rubin CM, Yingsin L, Ildefonso SR, Jol HM. 2015. Ground penetrating radar examination of thin tsunami beds - A case study from Phra Thong Island, Thailand. Sedimentary Geology 329: 149-165. DOI: 10.1016/j.sedgeo.2015.09.011 Hansom JD, Angus S. 2005. Machair nan Eilean Siar (Machair of the Western Isles). Scottish Geographical Journal 121: 401-411. DOI: 10.1080/00369220518737247 Hesp P. 2002. Foredunes and blowouts: initiation, geomorphology and dynamics. Geomorphology 48: 245-268. DOI: 10.1016/s0169-555x(02)00184-8 Jahnert R, de Paula O, Collins L, Strobach E, Pevzner R. 2012. Evolution of a coquina barrier in Shark Bay, Australia by GPR imaging: Architecture of a Holocene 
reservoir analog. Sedimentary Geology 281: 59-74. DOI:

https://doi.org/10.1016/j.sedgeo.2012.08.009

Jericho Project, 2000. UK wave climate analysis.

http://www.satoc.eu/sos/projects/Jericho/webpages/jeriuk.html,

Jol HM, Bristow CS. 2003. GPR in sediments: advice on data collection, basic

processing and interpretation, a good practice guide. Geological Society, London,

Special Publications 211: 9-27. DOI: 10.1144/gsl.sp.2001.211.01.02

Jordan JT, Smith DE, Dawson S, Dawson AG. 2010. Holocene relative sea-level

changes in Harris, Outer Hebrides, Scotland, UK. Journal of Quaternary Science 25:

115-134. DOI: $10.1002 / j q s .1281$

Manley G. 1979. The climatic environment of the Outer Hebrides. Proceedings of the Royal Society of Edinburgh. Section B. Biological Sciences 77: 47-59. DOI: Doi:

$10.1017 / \mathrm{s} 0269727000012628$

Mate ID. 1992. The theoretical development of machair in the Hebrides. Scottish

Geographical Magazine 108: 35-38. DOI: 10.1080/00369229218736840

Moss MR, Dickinson G. 1979. Evolution of the Dune and Machair Grassland Surface of South Uist, Outer Hebrides, Scotland. Environmental Conservation 6: 287-292.

DOI: $10.1017 / \mathrm{S} 0376892900003489$

Neal A. 2004. Ground-penetrating radar and its use in sedimentology: principles, problems and progress. Earth-Science Reviews 66: 261-330. DOI:

10.1016/j.earscirev.2004.01.004

Neal A, Richards J, Pye K. 2003. Sedimentology of coarse-clastic beach-ridge deposits, Essex, southeast England. Sedimentary Geology 162: 167-198. DOI:

$10.1016 / \mathrm{s} 0037-0738(03) 00136-2$ 
Neal A, Roberts CL. 2000. Applications of ground-penetrating radar (GPR) to sedimentological, geomorphological and geoarchaeological studies in coastal environments. Geological Society, London, Special Publications 175: 139-171. DOI: 10.1144/gsl.sp.2000.175.01.12

Oertel GF. 1985. The barrier island system. Marine Geology 63: 1-18

Orme LC, Reinhardt L, Jones RT, Charman DJ, Barkwith A, Ellis MA. 2016. Aeolian sediment reconstructions from the Scottish Outer Hebrides: Late Holocene storminess and the role of the North Atlantic Oscillation. Quaternary Science Reviews 132: 15-25. DOI: https://doi.org/10.1016/j.quascirev.2015.10.045 Pile J, Switzer AD, Soria L, Siringan F, Daag A. 2016. An investigation of recent storm histories using ground penetrating radar at Bay-Bay spit, Bicol, Central Philippines. In 2016 16th International Conference on Ground Penetrating Radar (GPR); $1-4$.

Richards LAR, Phipps PJ. 2011. Managing the impact of climate change on vulnerable areas: a case study of the Western Isles. In Institute of Civil Engineers Conference: Belfast, UK, December 2011.

Ritchie W. 1967. The Machair of South Uist. Scottish Geographical Magazine 83: 161-173. DOI: $10.1080 / 00369226708736056$

Ritchie W, 1971. The beaches of Barra and the Uists. A survey of the beach, dune and machair areas of Barra, South Uist, Benbecula, North Uist and Berneray. Commissioned Report No. 047, Ritchie W. 1976. The meaning and definition of machair. Transactions of the Botanical Society of Edinburgh 42: 431-440. DOI: 10.1080/03746607608685306 
Ritchie W. 1979. Machair development and chronology in the Uists and adjacent islands. Proceedings of the Royal Society of Edinburgh. Section B. Biological Sciences 77: 107-122. DOI: 10.1017/s0269727000012677

Ritchie W. 2005. Machair. In Encyclopedia of Coastal Science, Schartz M (ed). Springer: Dordrecht; 601-602.

Ritchie W, Whittington G, Edwards KJ. 2001. Holocene changes in the physiography and vegetation of the Atlantic littoral of the Uists, Outer Hebrides, Scotland.

Transactions of the Royal Society of Edinburgh: Earth Sciences 92: 121-136

Switzer AD, Bristow CS, Jones BG. 2006. Investigation of large-scale washover of a small barrier system on the southeast Australian coast using ground penetrating radar. Sedimentary Geology 183: 145-156. DOI: 10.1016/j.sedgeo.2005.09.015 Van Heteren S, FitzGerald D, McKinlay PA, Buynevich I. 1998. Radar facies of paraglacial barrier systems: coastal New England, USA. Sedimentology 45: 181-200 Wilson J, Watkins A, Rapson G, Bannister P. 1993 New Zealand machair vegetation. Journal of Vegetation Science 4: 655-660

Wolf $\mathrm{J}, 2007$. Modelling of waves and set-up for the storm of 11-12 January 2005.

Proudman Oceanographic Laboratory, Liverpool

Young EJ, McKenzie BM, McNicol JW, Robertson AHJ, Wendler R, Dawson S. 2015 Spatial trends in the wind abrasion resistance of cultivated machair soil, South Uist, Scottish Outer Hebrides. CATENA 135: 1-10. DOI: 10.1016/j.catena.2015.06.015 
Table 1: Core M1A

\begin{tabular}{|c|c|c|}
\hline $\begin{array}{l}\text { Depth } \\
\text { (m) }\end{array}$ & Description & Interpretation \\
\hline $0-0$ & $\begin{array}{l}\text { Dark brown, organic, sandy peat with } \\
\text { medium grained sand flecks and rootlets }\end{array}$ & $\begin{array}{l}\text { Present Machair surface/ } \\
\text { ploughed soil }\end{array}$ \\
\hline 0.1 & $\begin{array}{l}\text { Dark brown, organic, peaty medium grained } \\
\text { sand with rootlets. }\end{array}$ & $\begin{array}{l}\text { Former Machair } \\
\text { surface/soil horizon }\end{array}$ \\
\hline 0.20 & Dark brown, organic rich, sandy peat & Machair soil \\
\hline 0.25 & $\begin{array}{l}\text { Medium to light greyish brown, medium to } \\
\text { coarse grained shelly sand } \\
\text { Water table encountered at } 0.3 \mathrm{~m}\end{array}$ & Wind-blown sand \\
\hline 0.35 & $\begin{array}{l}\text { Medium greyish brown, coarse grained } \\
\text { shelly sand with organic horizon at } 0.39 \mathrm{~m}\end{array}$ & $\begin{array}{l}\text { Wind-blown sand } \\
\text { Organic horizon, possible } \\
\text { former stable } \\
\text { dune/vegetation surface }\end{array}$ \\
\hline $0.40-0.70$ & $\begin{array}{l}\text { Medium to light brownish grey coarse } \\
\text { grained shelly sand with organic horizon at } \\
0.42 \mathrm{~m} \\
\text { No further penetration or sample recovery } \\
\text { due to sand moving up auger hole }\end{array}$ & $\begin{array}{l}\text { Wind-blown sand } \\
\text { Organic horizon, possible } \\
\text { former dune vegetation } \\
\text { surface }\end{array}$ \\
\hline
\end{tabular}


Table 2: Core M1B

\begin{tabular}{|c|c|c|}
\hline $\begin{array}{l}\text { Depth } \\
(\mathrm{m})\end{array}$ & Description & Interpretation \\
\hline $0-0.25$ & $\begin{array}{l}\text { Dark brown organic rich peat with medium } \\
\text { to coarse grained sand and shell flecks and } \\
\text { matted roots } \\
\text { Water table at } 0.05 \mathrm{~m}\end{array}$ & Wet flush \\
\hline $0.25-0.60$ & $\begin{array}{l}\text { Medium greyish brown, firm, organic rich, } \\
\text { silty, medium to coarse grained sandy soil } \\
\text { with shell fragments }\end{array}$ & Lake edge deposits \\
\hline $0.60-0.80$ & $\begin{array}{l}\text { Medium brownish grey, medium to coarse } \\
\text { grained, shelly sand with organic horizons at } \\
0.66 \text { and } 0.74 \mathrm{~m} .\end{array}$ & $\begin{array}{l}\text { Dune deposits } \\
\text { Organic horizons - } \\
\text { possible short term stable } \\
\text { dune/vegetation surface }\end{array}$ \\
\hline $0.80-0.95$ & $\begin{array}{l}\text { Dark greyish brown, organic, fine to medium } \\
\text { grained silty sand with rootlets }\end{array}$ & $\begin{array}{l}\text { Vegetated inter-dune } \\
\text { area (dune slack?) }\end{array}$ \\
\hline $0.95-1.20$ & $\begin{array}{l}\text { Light brownish grey, medium to coarse } \\
\text { grained shelly sand }\end{array}$ & $\begin{array}{l}\text { Dune deposits - infilling } \\
\text { of lake? }\end{array}$ \\
\hline $1.20-1.35$ & $\begin{array}{l}\text { Dark greyish brown, organic clayey silt with } \\
\text { fine to medium grained sand and shell } \\
\text { fragments }\end{array}$ & $\begin{array}{l}\text { Lake deposits - possible } \\
\text { signs of infilling by } \\
\text { aeolian sediments. }\end{array}$ \\
\hline $1.35-1.5$ & Dark grey-brown silty clay & Lake deposits \\
\hline 1.5 & $\begin{array}{l}\text { No penetration - auger "clinked" (metal on } \\
\text { rock sound), slight damage to auger "head" } \\
\text { observed when withdrawn from hole. }\end{array}$ & $\begin{array}{l}\text { Bedrock - Lewisian } \\
\text { Gneiss }\end{array}$ \\
\hline
\end{tabular}

This article is protected by copyright. All rights reserved. 
Table 3: Core OM1A

\begin{tabular}{|l|l|l|}
\hline $\begin{array}{l}\text { Depth } \\
\text { (m) }\end{array}$ & Description & Interpretation \\
\hline $0-0.05$ & $\begin{array}{l}\text { Dark-greyish black, organic rich, medium to } \\
\text { coarse grained shelly sand with rootlets. }\end{array}$ & $\begin{array}{l}\text { Present Machair } \\
\text { top/plough soil }\end{array}$ \\
\hline $0.05-0.20$ & $\begin{array}{l}\text { Medium to light-grey, medium to coarse } \\
\text { shelly sand with rootlets }\end{array}$ & Present Machair sub soil \\
\hline $0.20-0.28$ & $\begin{array}{l}\text { Dark-grey organic rich, coarse to medium } \\
\text { grained shelly sand with rootlets }\end{array}$ & $\begin{array}{l}\text { Former Machair } \\
\text { surface/plough soil }\end{array}$ \\
\hline $0.28-0.40$ & $\begin{array}{l}\text { Medium to light grey, coarse grained shelly } \\
\text { sand with some rootlets }\end{array}$ & Former Machair subsoil \\
\hline $0.40-0.50$ & $\begin{array}{l}\text { Fairly clean, light grey, medium to coarse } \\
\text { grained shelly sand } \\
\text { Water table encountered at 0.5m - no } \\
\text { further recovery of sample due to flowing } \\
\text { sand. }\end{array}$ & $\begin{array}{l}\text { Pre-Machair surface, } \\
\text { possible winnowed sand } \\
\text { sheet facies. }\end{array}$ \\
\hline
\end{tabular}


Table 4:Core OM1B

\begin{tabular}{|l|l|l|}
\hline $\begin{array}{l}\text { Depth } \\
(\mathbf{m})\end{array}$ & Description & Interpretation \\
\hline $0-0.05$ & $\begin{array}{l}\text { Dark to light-grey, medium to coarse shelly } \\
\text { sand with rootlets }\end{array}$ & $\begin{array}{l}\text { present Machair (Hillock } \\
\text { Zone) soil }\end{array}$ \\
\hline $0.05-0.25$ & $\begin{array}{l}\text { Light brownish-grey, medium grained shelly } \\
\text { sand }\end{array}$ & Hillock aggradation \\
\hline $0.25-0.47$ & $\begin{array}{l}\text { Light greyish brown, coarse grained shelly } \\
\text { sand }\end{array}$ & $\begin{array}{l}\text { Hillock formation above } \\
\text { former land surface }\end{array}$ \\
\hline $0.47-0.56$ & $\begin{array}{l}\text { Dark grey-black, organic rich, medium } \\
\text { grained shelly sand with rootlets }\end{array}$ & $\begin{array}{l}\text { Former Machair } \\
\text { surface/soil }\end{array}$ \\
\hline $0.56-0.60$ & $\begin{array}{l}\text { Clean, light grey, medium grained shelly } \\
\text { sand, with some coarser shell fragments. } \\
\text { Poor recovery of sample due to high water- } \\
\text { table and flowing sand - no further sample } \\
\text { recovery. }\end{array}$ & $\begin{array}{l}\text { Pre-Machair surface, } \\
\text { possible winnowed sand } \\
\text { sheet facies. }\end{array}$ \\
\hline
\end{tabular}


Table 5 and 5a: Core OM1C and Core OM1Ca

\begin{tabular}{|c|c|c|}
\hline $\begin{array}{l}\text { Depth } \\
\text { (m) }\end{array}$ & Description & Interpretation \\
\hline $0-0$. & $\begin{array}{l}\text { Dark black, organic, sandy peat with } \\
\text { medium to coarse grained shell fragments } \\
\text { Water ponding on surface }\end{array}$ & present Machair soil \\
\hline $0.15-0.20$ & $\begin{array}{l}\text { Clean, light grey, coarse to very coarse } \\
\text { grained shelly sand, with occasional very } \\
\text { fine gravel clast } \\
\text { Water table effectively at surface, poor } \\
\text { recovery of sample due to sand and water } \\
\text { flowing up auger hole once overburden } \\
\text { removed - no further sample recovery. }\end{array}$ & $\begin{array}{l}\text { Pre-Machair surface, } \\
\text { possible winnowed sand } \\
\text { sheet }\end{array}$ \\
\hline $\begin{array}{l}\text { Depth } \\
\text { (m) }\end{array}$ & Description & Interpretation \\
\hline & $\begin{array}{l}\text { Dark black, organic, medium grained peaty } \\
\text { sand with rootlets } \\
\text { Water ponding on surface }\end{array}$ & $\begin{array}{l}\text { present Machair soil - } \\
\text { significant lateral } \\
\text { variation - OM1Ca } \\
\text { approx. } 0.3 \mathrm{~m} \text { away from } \\
\text { OM1C }\end{array}$ \\
\hline $0.15-0.20$ & $\begin{array}{l}\text { Clean, light grey, coarse to very coarse } \\
\text { grained shelly sand, with some larger shell } \\
\text { fragments } \\
\text { Water table effectively at surface, poor } \\
\text { recovery of sample due to sand and water } \\
\text { flowing up auger hole once overburden } \\
\text { removed - no further sample recovery. }\end{array}$ & $\begin{array}{l}\text { Pre-Machair surface, } \\
\text { possible winnowed sand } \\
\text { sheet }\end{array}$ \\
\hline
\end{tabular}

OM1Ca

This article is protected by copyright. All rights reserved. 
Table 6: Core BS1A

\begin{tabular}{|l|l|l|}
\hline $\begin{array}{l}\text { Depth } \\
(\mathbf{m})\end{array}$ & Description & Interpretation \\
\hline $0-0.20$ & $\begin{array}{l}\text { Matrix of coarse grained organic-rich shelly } \\
\text { sand with 35-60 mm pebbles. }\end{array}$ & $\begin{array}{l}\text { Present Dune /Machair } \\
\text { surface with storm debris } \\
\text { derived from beach }\end{array}$ \\
\hline $0.20-0.38$ & $\begin{array}{l}\text { mixed coarse grained gravelly sand with } \\
\text { well rounded 18-30 mm clasts. }\end{array}$ & $\begin{array}{l}\text { Possible washover } \\
\text { deposits }\end{array}$ \\
\hline $0.38-0.44$ & coarse grained shelly sand & Machair sand \\
\hline $0.44-0.46$ & $\begin{array}{l}\text { black organic rich coarse grained sand } \\
\text { overlying layer of 5-12 mm rounded to well- } \\
\text { rounded gravel clasts }\end{array}$ & $\begin{array}{l}\text { Former vegetated } \\
\text { Machair /Dune surface }\end{array}$ \\
\hline $0.46-0.75$ & $\begin{array}{l}\text { light brownish grey coarse grained sand with } \\
\text { rootlets and thin black organic rich sand } \\
\text { layers at 0.49 and 0.51m }\end{array}$ & $\begin{array}{l}\text { Machair /Dune soil } \\
\text { horizon }\end{array}$ \\
\hline $0.75-1.02$ & $\begin{array}{l}\text { Medium to light grey, medium to fine grained } \\
\text { sand with occasional rounded to well- } \\
\text { rounded pebbles (20mm). } \\
\text { No further penetration or sample recovery } \\
\text { due to encountering compacted sedimentary } \\
\text { layer. }\end{array}$ & \\
\hline & Beach /Dune sediment \\
\hline
\end{tabular}

Table 7: Core BS2A

\begin{tabular}{|l|l|l|}
\hline $\begin{array}{l}\text { Depth } \\
\text { (m) }\end{array}$ & Description & Interpretation \\
\hline $0-0.10$ & $\begin{array}{l}\text { Dark greyish brown, medium grained sand } \\
\text { with rootlets }\end{array}$ & Present soil horizon \\
\hline $0.10-0.20$ & $\begin{array}{l}\text { Medium greyish brown, medium grained } \\
\text { sand }\end{array}$ & Present sub-soil \\
\hline $0.20-1.15$ & $\begin{array}{l}\text { Light brownish grey, medium grained sand } \\
\text { Sand becoming damp at 0.7m } \\
\text { Damp sand compacted layer at 1.15m - no } \\
\text { further penetration/sample recovery. }\end{array}$ & $\begin{array}{l}\text { Machair/dune sand } \\
\text { NB: unlike BS1A - no } \\
\text { gravel/pebble horizons or } \\
\text { organic layers - rapid } \\
\text { aeolian deposition? }\end{array}$ \\
\hline
\end{tabular}


Table 8: Main Radar Facies and bounding surfaces identified within the Machair traverses

\begin{tabular}{|c|c|c|c|c|}
\hline $\begin{array}{l}\text { Radar } \\
\text { Facies }\end{array}$ & Name & Description & Interpretation & Figure/Location \\
\hline Facies 1 & $\begin{array}{l}\text { Hyperbolic } \\
\text { facies }\end{array}$ & $\begin{array}{l}\text { Undulating uneven } \\
\text { surface characterised by } \\
\text { abundant multiple } \\
\text { overlapping hyperbolae } \\
\text { and signal attenuation. } \\
\text { This facies is generally } \\
\text { reflection free below the } \\
\text { uneven top surface; with } \\
\text { occasional bright } \\
\text { reflections possibly } \\
\text { caused by sideswipe } \\
\text { from objects located } \\
\text { away from the main } \\
\text { transect line. }\end{array}$ & $\begin{array}{l}\text { Bedrock - } \\
\text { Lewisian } \\
\text { Gneiss. }\end{array}$ & $\begin{array}{l}\text { Figures } 3 \text { and } 4, \\
\text { Milton and } \\
\text { Ormicalte }\end{array}$ \\
\hline Facies 2 & $\begin{array}{l}\text { Inclined } \\
\text { planar } \\
\text { reflections }\end{array}$ & $\begin{array}{l}\text { High amplitude reflection, } \\
\text { good penetration, steeply } \\
\text { dipping reflections, } 1: 17 \\
\text { to } 1: 2.5 \text { linear to } \\
\text { sigmoidal. Continuous } \\
\text { over } 10 \text { s of metres }\end{array}$ & $\begin{array}{l}\text { Large scale } \\
\text { dunes cross } \\
\text { bedding - } \\
\text { apparent } \\
\text { relative } \\
\text { younging from } \\
\text { seaward to } \\
\text { landward (west } \\
\text { to east). }\end{array}$ & $\begin{array}{l}\text { Figure 5, } \\
\text { Baleshare }\end{array}$ \\
\hline Facies 3 & $\begin{array}{l}\text { Concave } \\
\text { sub } \\
\text { horizontal } \\
\text { facies }\end{array}$ & $\begin{array}{l}\text { Concave, shallow to sub- } \\
\text { horizontal landward } \\
\text { dipping reflections } \\
\text { overlying and onlapping } \\
\text { steeply dipping } \\
\text { reflections of RF } 2 \text { (at } \\
\text { Baleshare) and RF1 } \\
\text { (Milton) }\end{array}$ & $\begin{array}{l}\text { landward } \\
\text { extent of } \\
\text { machair zone. } \\
\text { Freshwater } \\
\text { marsh } \\
\text { deposits }\end{array}$ & $\begin{array}{l}\text { Figures } 3 \text { and 5, } \\
\text { Milton } \\
\text { Baleshare }\end{array}$ \\
\hline $\begin{array}{l}\text { Facies } 4 \\
\\
5=-1\end{array}$ & $\begin{array}{l}\text { Sub } \\
\text { horizontal } \\
\text { undulating } \\
\text { facies }\end{array}$ & $\begin{array}{l}\text { laterally continuous, near } \\
\text { uniform thickness, flat } \\
\text { upper surface undulating } \\
\text { reflection over } 10 \text { s to } \\
100 \text { s metres. Typically } \\
1.5-2 \mathrm{~m} \text { thick. Surface } \\
\text { scoops (Baleshare) c. } \\
30 \mathrm{~m} \text { across and filled } \\
\text { with sub-horizontal } \\
\text { reflections. }\end{array}$ & $\begin{array}{l}\text { Machair facies } \\
\text { (distal } \\
\text { machair) - } \\
\text { each unit of } \\
\text { sand bounded } \\
\text { by reflection = } \\
\text { depositional } \\
\text { episode } \\
\text { followed by } \\
\text { stability. } \\
\text { Surface } \\
\text { scoops = }\end{array}$ & $\begin{array}{l}\text { Figures 3-5, } \\
\text { Milton, } \\
\text { Ormiclate and } \\
\text { Baleshare }\end{array}$ \\
\hline
\end{tabular}




\begin{tabular}{|c|c|c|c|c|}
\hline & & & $\begin{array}{l}\text { blowout or } \\
\text { deflation } \\
\text { hollow - } \\
\text { possibly } \\
\text { associated } \\
\text { with parabolic } \\
\text { dune } \\
\text { migration. } \\
\text { Implication for } \\
\text { machair } \\
\text { evolution } \\
\text { model. }\end{array}$ & \\
\hline Facies 5 & $\begin{array}{l}\text { Stacked } \\
\text { horizontal } \\
\text { reflections } \\
\text { with } \\
\text { hyperbolae }\end{array}$ & $\begin{array}{l}\text { Seaward edge }-100 \mathrm{~m} \\
\text { wide. Stacked sub- } \\
\text { horizontal reflections with } \\
\text { numerous surface/near } \\
\text { surface overlapping } \\
\text { hyperbolae. Dipping } \\
\text { slightly seaward, } \\
\text { accretionarty, up to } 11 \mathrm{~m} \\
\text { elevation, } 2 \mathrm{~m} \text { thick. }\end{array}$ & $\begin{array}{l}\text { vertical } \\
\text { accumulation } \\
\text { of sand } \\
\text { derived from } \\
\text { erosion of } \\
\text { adjacent } \\
\text { beach. Surface } \\
\text { hyperbolae = } \\
\text { rabbit burrows }\end{array}$ & Figure 3, Milton \\
\hline Facies 6 & $\begin{array}{l}\text { Chaotic } \\
\text { facies } \\
\text { (lateral } \\
\text { facies } \\
\text { equivalent } \\
\text { of F5) }\end{array}$ & $\begin{array}{l}\text { Seaward edge, } 100 \mathrm{~m} \\
\text { wide, tapering wedge } 2 \mathrm{~m} \\
\text { wide at seaward edge. } \\
\text { Discontinuous, chaotic } \\
\text { reflections }\end{array}$ & $\begin{array}{l}\text { stoss side of } \\
\text { foredune (slip } \\
\text { face) }\end{array}$ & $\begin{array}{l}\text { Figure 4, } \\
\text { Ormiclate }\end{array}$ \\
\hline $\begin{array}{l}\text { Facies } 7 \\
\end{array}$ & $\begin{array}{l}\text { Hummocks } \\
\text { and hollows }\end{array}$ & $\begin{array}{l}\text { ca } 1-1.5 \mathrm{~m} \text { high, } 10 \mathrm{~m} \text { wide } \\
\text { surface expression. } \\
\text { Internal structure not } \\
\text { imaged, due to resolution } \\
\text { of radar. Separated by } \\
10 \mathrm{~m} \text {-wide hollows filled } \\
\text { with sediment }<1 \mathrm{~m} \text { thick. } \\
\text { Facies extends for } 300 \mathrm{~m} \\
\text { in shore normal } \\
\text { dimension and rests on } \\
\text { Facies } 4\end{array}$ & $\begin{array}{l}\text { isolated dune } \\
\text { ridges resting } \\
\text { on marsh } \\
\text { surface and } \\
\text { separated by } \\
\text { inter-dune } \\
\text { depressions } \\
\text { and associated } \\
\text { wet and } \\
\text { muddy } \\
\text { sediments } \\
\end{array}$ & $\begin{array}{l}\text { Figure 4, } \\
\text { Ormiclate }\end{array}$ \\
\hline Facies 8 & $\begin{array}{l}\text { Seaward } \\
\text { dipping } \\
\text { reflections }\end{array}$ & $\begin{array}{l}\text { Concave, dipping } \\
\text { reflections forming } \\
\text { seaward side ofa } \\
\text { topographic high and } \\
\text { onlapping/overlying } \\
\text { Facies } 4\end{array}$ & $\begin{array}{l}\text { Dune } \\
\text { (windward } \\
\text { side) infilling } \\
\text { deflation } \\
\text { hollow in RF4 }\end{array}$ & $\begin{array}{l}\text { Figure 5a, } \\
\text { Baleshare BS1 }\end{array}$ \\
\hline
\end{tabular}

This article is protected by copyright. All rights reserved. 


\begin{tabular}{|c|c|c|c|c|}
\hline $\begin{array}{l}\text { Bounding } \\
\text { Surface }\end{array}$ & $\begin{array}{l}\text { Bright, } \\
\text { ground } \\
\text { following, } \\
\text { paired } \\
\text { reflection }\end{array}$ & $\begin{array}{l}\text { Laterally continuous } \\
\text { paired reflection, approx. } \\
1-1.5 \mathrm{~m} \text { below and } \\
\text { generally following the } \\
\text { ground surface. Closer to } \\
\text { ground surface at lower } \\
\text { elevations, and } \\
\text { horizontal-sub horizontal } \\
\text { trend below higher } \\
\text { elevation dune type } \\
\text { features. It is seen to cut } \\
\text { across some dipping } \\
\text { reflections, whilst others } \\
\text { appear to pass through it. }\end{array}$ & $\begin{array}{l}\text { Water table } \\
\text { (WT) }\end{array}$ & All profiles. \\
\hline
\end{tabular}




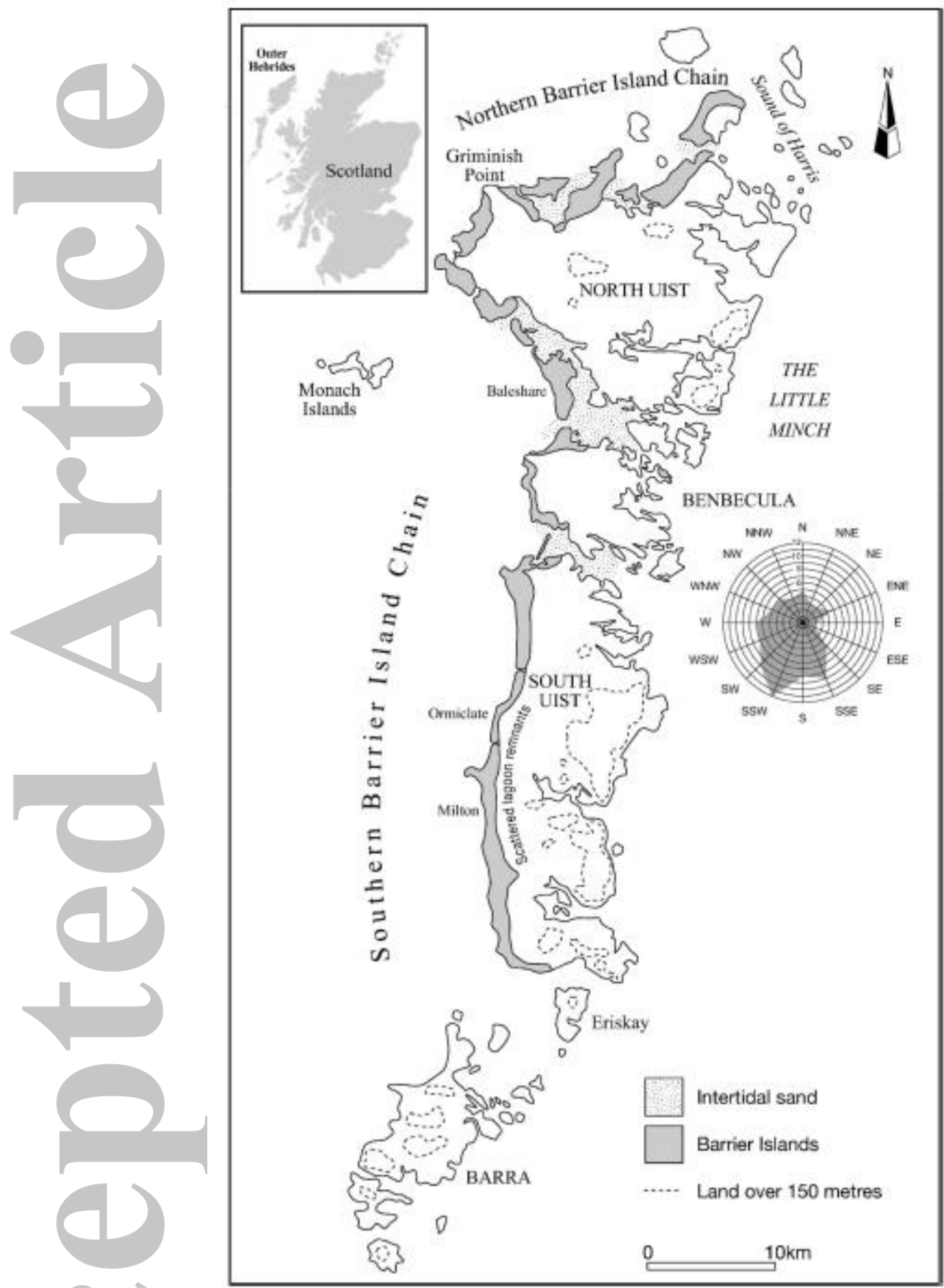

Figure 1: Location map of Western Isles showing locations of GPR traverse lines. The wind rose shows the dominant wind direction from SSW.

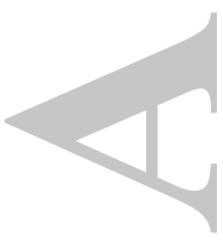




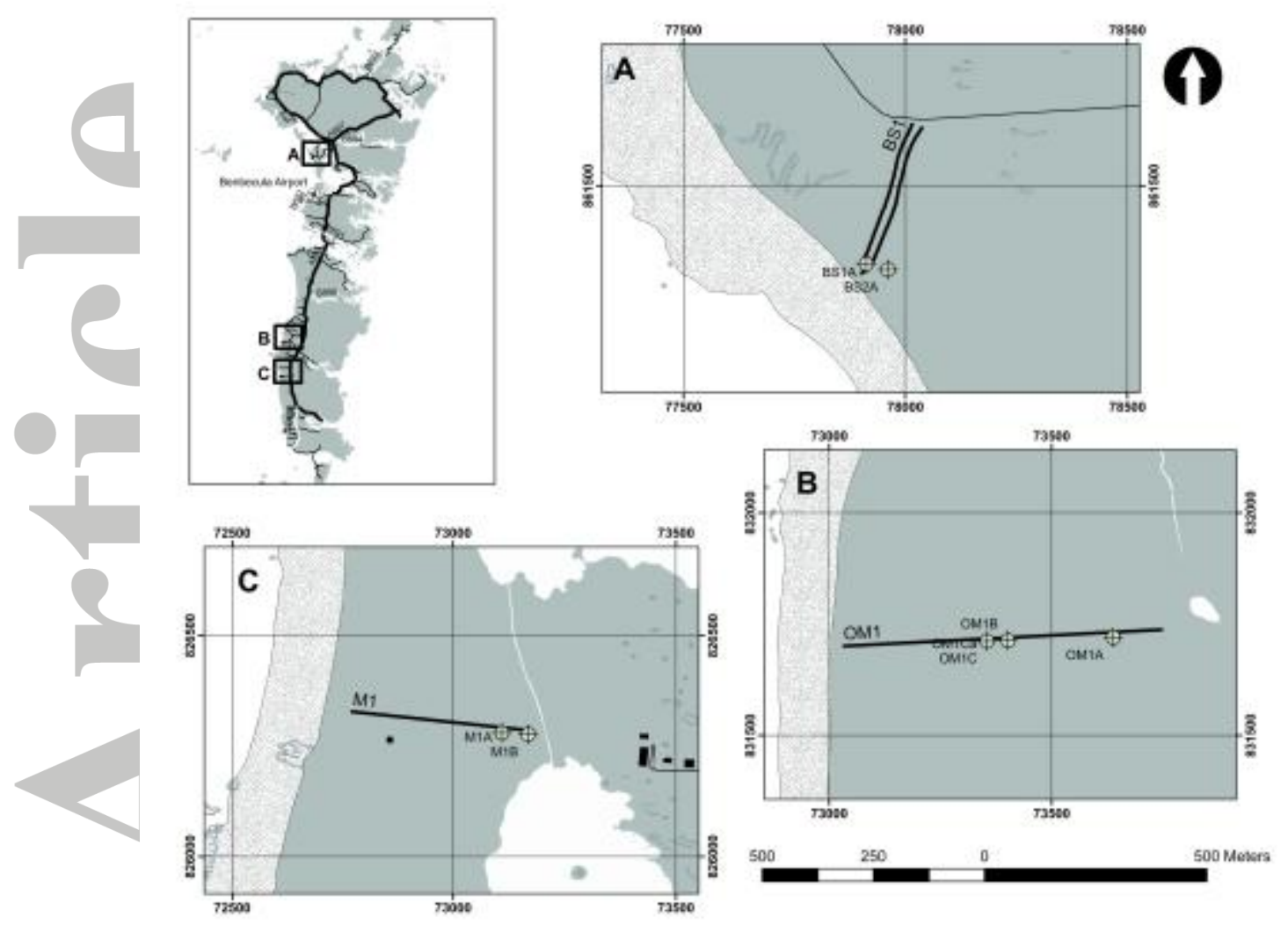

Figure 2: Overview map and maps of study sites. Boxed areas on overview map show locations of the study sites. From North to South, A: Site map of Baleshare GPR traverse lines and boreholes, B: Site map of Ormiclate GPR traverse line and boreholes and C: Site map of Milton GPR traverse line and boreholes. Contains Ordnance Survey data (C) Crown copyright and database right 2010 


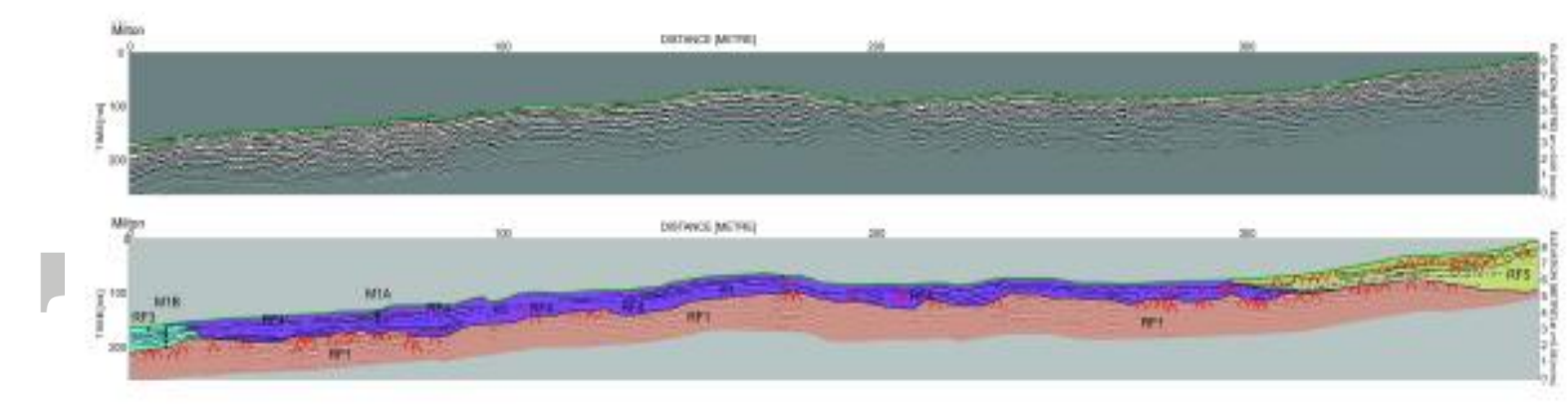

Figure 3: Milton GPR Profile line (above) and interpretation (below) - profile direction east to west (landward to seaward). Radar Facies (RF) 1 is overlain by RF4 over most of the profile length. At the landward (lower elevation) end, RF4 passes into RF3, with a minor change in the orientation of the reflections. At approximately 300 $\mathrm{m}$ along profile RF5 directly overlies RF4 and at $320 \mathrm{~m}$ along profile directly overlies RF1. WT (Blue line) $=$ Water Table

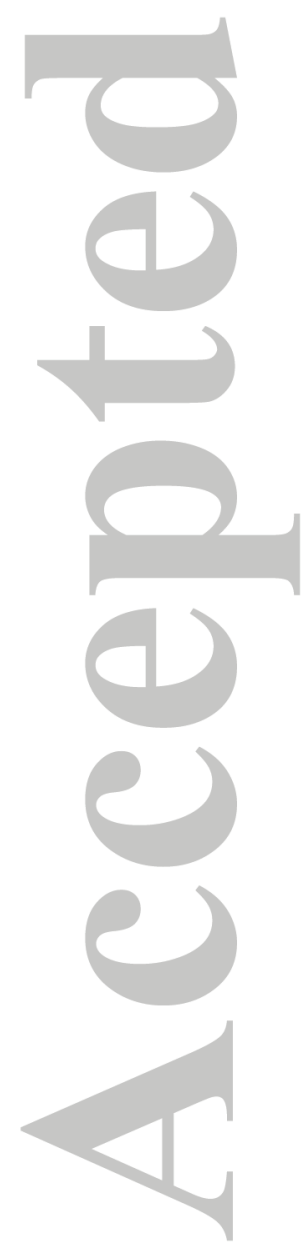



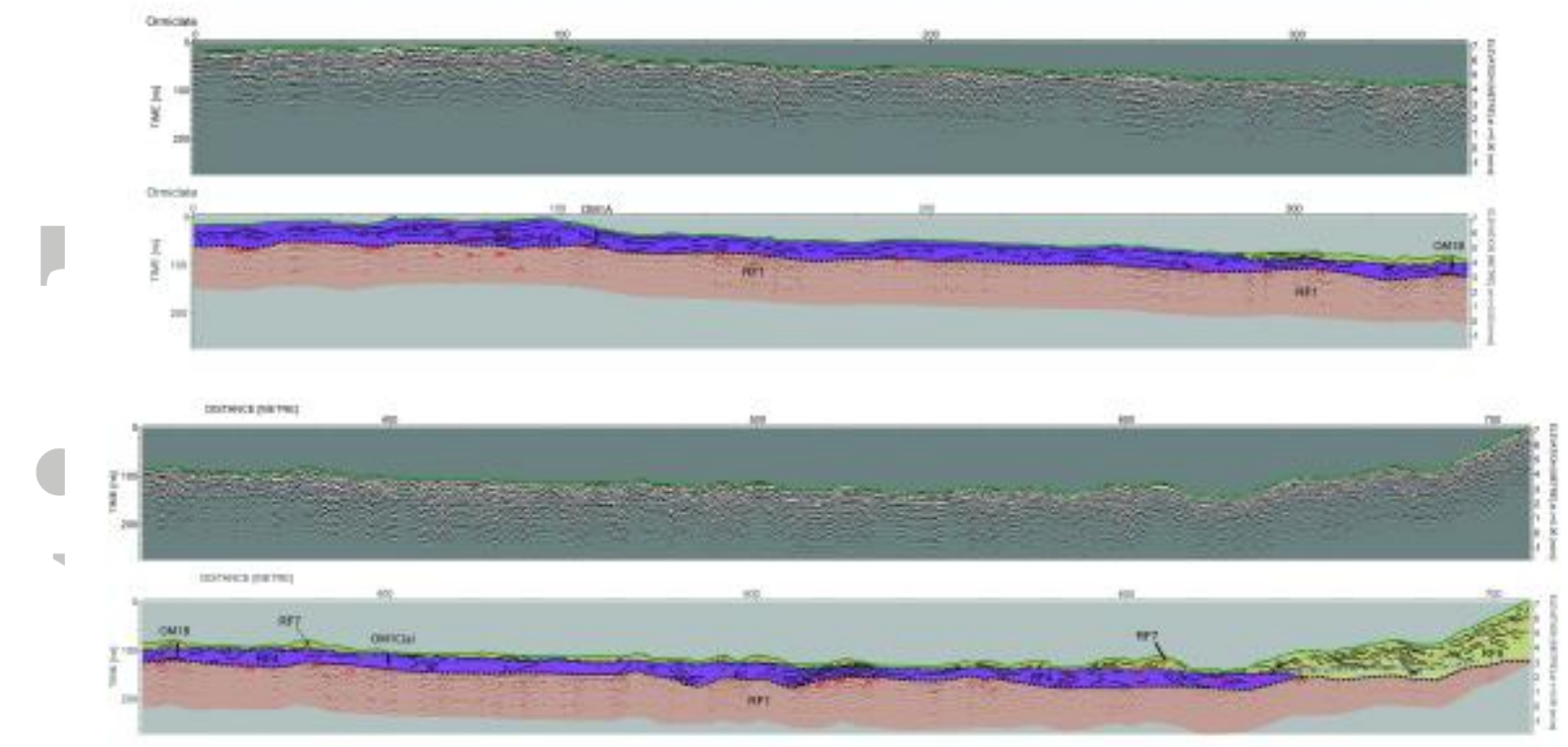

Figure 4: Ormiclate GPR line (OM1) - split profile - landward to mid-profile (top) and mid-profile to seaward (bottom). Interpretation is presented below the uninterpreted section in each case. Over the majority of the $700 \mathrm{~m}$ profile, RF4 directly overlies RF1. $280 \mathrm{~m}$ along profile, RF7 forms a thin layer overlying RF4. Further seaward, $625 \mathrm{~m}$ along profile, RF7 is replaced by RF5, which overlies RF4 for approximately 5 m, before directly overlying RF1. WT (Blue line) = Water Table 


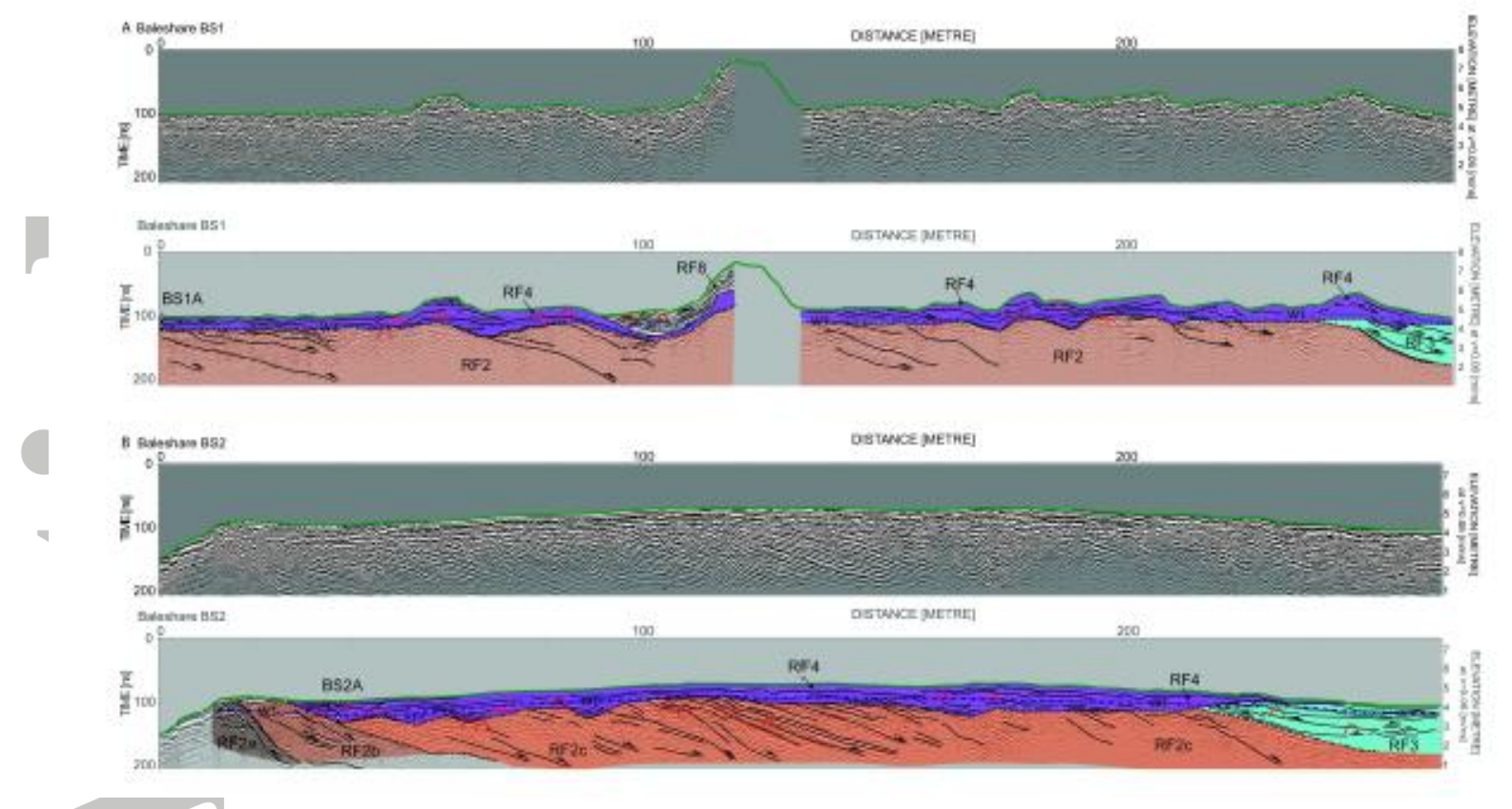

Figure 5: Baleshare GPR Lines. (A) GPR line BS1 (above) and interpretation (below). Gap in profile due to steep topography. RF4 overlies RF2 which comprises a series of landward dipping reflections, which merge with the slightly more concave, dipping landward dipping reflections of RF3, which is also overlain by RF4. Seaward dipping reflections of RF8 overlie and onlap RF4. (B) GPR line BS2 (above) and interpretation (below). Profile direction seaward to landward (west to east). RF1 is again absent from the profile. The landward dipping reflections of RF2 are steeper at the western end of the profile, indicated by sub-facies RF2a and RF2b, although all reflections appear conformable with RF2c. The sub-horizontal reflections of RF4 appear to truncate the underlying dipping reflections of RF2, which again merges with the shallower, concave, reflections of RF3. WT (Blue line) = Water Table 

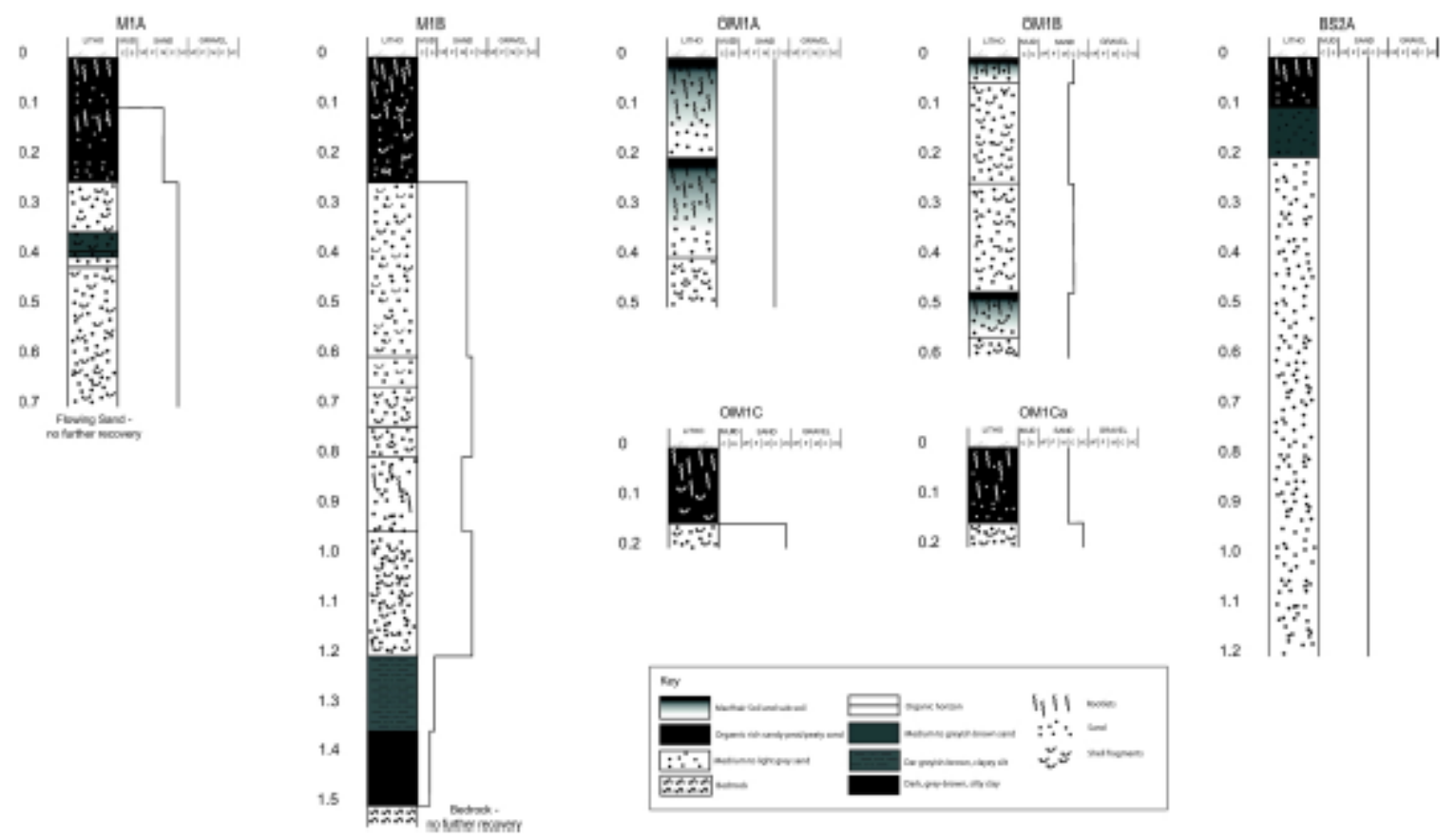

Figure 6: Graphic logs of boreholes M1A and M1B (Milton); OM1A, OM1B, OM1C and OM1Ca (Ormiclate); BS2A (Baleshare). Greatest amount of core recovery was from $\mathrm{M} 1 \mathrm{~B}$ and $\mathrm{BS} 2 \mathrm{~A}$, with $\mathrm{M} 1 \mathrm{~B}$ reaching bedrock at $1.5 \mathrm{~m}$, as indicated by interpretation of radar data.

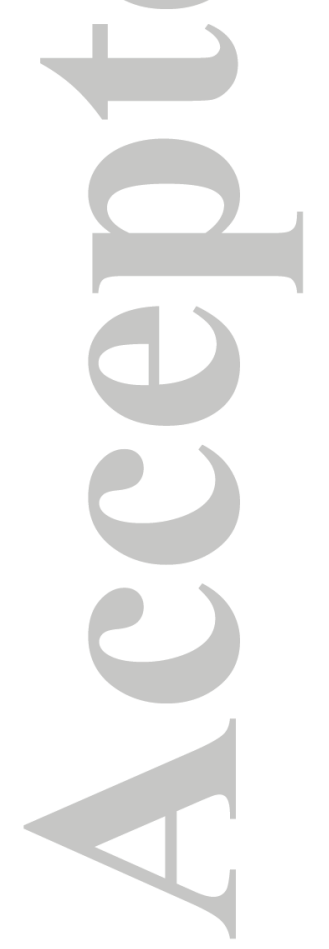




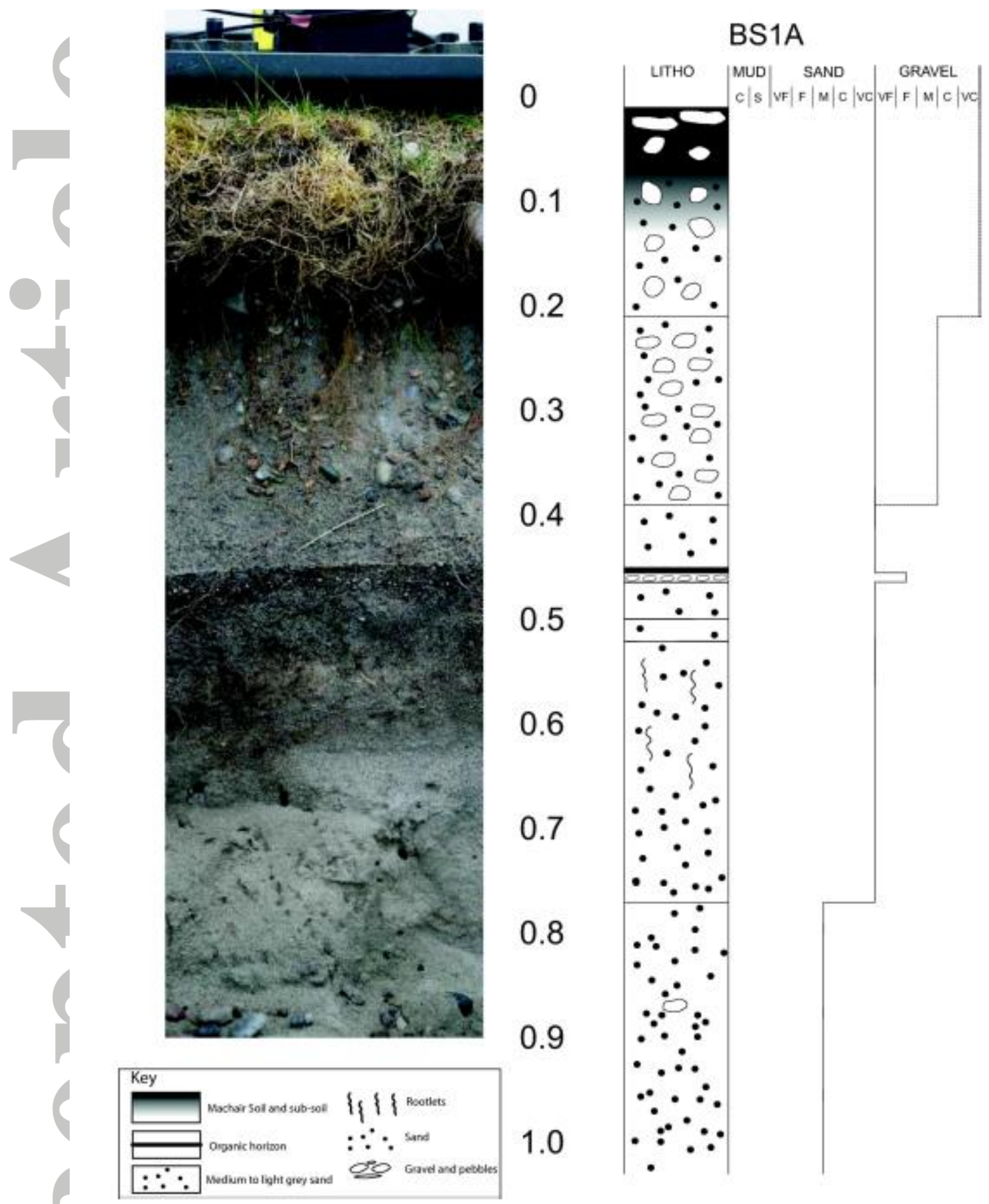

Figure 7: Cliffed machair section at seaward end of Radar line BS1 - Baleshare showing sedimentary sequence of RF4 at this location (old soil horizon $0.44 \mathrm{~m}$ below ground surface - resolvable on radargram - Figure 5a) 